\title{
Analisis Fungsi Partai Politik Pada Pilkada Musi Banyuasin 2017 (Studi Terhadap Partai Politik Pengusung Pasangan Dodi Reza Dan Beni Hernedi)
}

\author{
Erik Darmawan, Anis Septiana \\ Fakultas Ilmu Sosial dan Ilmu Politik Universitas Islam Negeri Raden Fatah Palembang \\ Email: anisseptiana97@gmail.com
}

\begin{abstract}
Political parties are official organizations created by people who have interests and goals to control the government, by placing their members in the government through an election mechanism. The election process is inseparable from political parties, because political parties can channel the aspirations of the people, where the people can participate in it and have a strong influence on the election. The main function of political parties is to seek power, gain power and maintain it. In the 2017 Musi Banyuasin Local Election, the pairs of Dodi Reza and Beni Hernedi were carried out by 11 (eleven) political parties namely PDIP, Golkar, Democrat, Hanura, Nasdem, and PKB. As the party supporting the pair Dodi Reza and Beni Hernedi in the 2017 Musi Banyuasin Regional Election, political parties should fight in giving victory to the candidate pair that they carry by carrying out the functions of political parties as well as possible. Issues that will be discussed in this study include how the function of political parties in winning sub-regional elections and how the functions of political parties supporting the pair Dodi Reza and Beni Hernedi are assessed from the results of votes in the 2017 Musi Banyuasin Regional Election.This type of research is field research, while the type of research is qualitative, where the research procedure produces a description, which describes and describes matters relating to the problem of the function of political parties. The rationale that the researchers used in this study is the framework of thinking from Miriam Budiardjo to explain the function of political parties. The results of this study indicate that the function of political parties carried out by the party supporting the pair Dodi Reza and Beni Hernedi has not run optimally, this is evident from the high level of abstentions in the Musi Banyuasin elections in 2017.
\end{abstract}

Keywords: political party, local election

\begin{abstract}
Abstrak
Partai politik adalah organisasi resmi yang dibuat oleh orang-orang yang memiliki kepentingan dan tujuan untuk menguasai pemerintahan, dengan cara menempatkan anggotanya dalam
\end{abstract}


pemerintahan melalui mekanisme pemilu. Proses pemilu tidak terlepas dari partai politik, karena partai politik dapat menyalurkan aspirasi rakyat, dimana rakyat dapat ikut didalamnya dan berpengaruh kuat dalam pemilu. Fungsi utama dari partai politik ialah mencari kekuasaan, mendapatkan kekuasaan, dan mempertahankannya. Pada Pilkada Musi Banyuasin 2017 paslon Dodi Reza dan Beni Hernedi diusung oleh 11 (sebelas) partai politik yaitu PDIP, Golkar, Demokrat, Hanura, Nasdem, dan PKB. Sebagai partai pengusung pasangan Dodi Reza dan Beni Hernedi pada Pilkada Musi Banyuasin 2017 partai politik seharusnya berjuang dalam memberikan kemenangan bagi paslon yang diusungnya dengan cara menjalankan fungsi partai politik dengan sebaik-baiknya. Permasalahan yang akan dibahas dalam penelitian ini antara lain Bagaimana fungsi partai politik dalam memenangkan subuah pemilihan kepala daerah dan Bagaimana fungsi partai politik pengusung pasangan Dodi Reza dan Beni Hernedi dinilai dari hasil perolehan suara pada Pilkada Musi Banyuasin 2017.Jenis penelitian ini adalah penelitian lapangan, sedangkan tipe penelitian ini adalah kualitatif, dimana prosedur penelitian ini menghasilkan sebuah deskripsi, yakni mengambarkan dan menjabarkan hal yang berkaitan dengan masalah fungsi partai politik. Adapun landasan pemikiran yang peneliti gunakan dalam penelitian ini yaitu kerangka pemikiran dari Miriam Budiardjo untuk menjelaskan mengenai fungsi partai politik. Hasil penelitian ini menunjukan bahwa fungsi partai politik yang dijalankan oleh partai pengusung pasangan Dodi Reza dan Beni Hernedi belum berjalan dengan maksimal, hal ini terbukti dari tingginya tingkat golput pada Pilkada Musi Banyuasin tahun 2017.

Kata kunci : pilkada, kandidat, strategi, kampanye

\section{PENDAHULUAN}

Pada tahun 2017 pemilihan kepala daerah dilakukan secara serentak di seluruh Indonesia, termasuk di Sumatera Selatan tepatnya Kabupaten Musi Banyuasin, untuk pemilihan kepala daerah di tingkat kabupaten atau sering disebut dengan pemilihan Bupati. Dalam pemilihan tersebut terdapat 2 kandidat yaitu pasangan Dodi Reza Alex - Beni Hernedi dan pasangan Amiri Arifin - Ahmad Toha. Dodi Reza Alex merupakan putra sulung Alex Noerdin yang pada saat itu menjabat sebagai Gubernur Sumatera Selatan. Pada tahun 2012 lalu, Dodi Reza maju sebagai calon bupati Musi Banyuasin namun kalah melawan pasangan Pahri Azhari dan Beni Hernedi.

Pada saat pilkada Musi Banyuasin 2017 pasangan calon pertama, Dodi Reza Alex Noerdin sebagai Bupati bersama Beni Hernedi sebagai Wakil Bupati dengan partai pengusung 11 partai yaitu Partai Demokrasi Indonesia Perjuangan (PDIP), Partai Amanat Nasional (PAN), Partai Gerakan Indonesia Raya (Gerindra), Partai Demokrat, Partai Golongan Karya (Golkar), Partai Nasional Demokrat (Nasdem), Partai Kebangkitan Bangsa (PKB), Partai Keadilan Sejahtera (PKS), Partai Hati Nurani Rakyat (Hanura), Partai Persatuan Pembangunan (PPP), Partai Bulan Bintang (PBB). Sedangkan pasangan calon kedua, Amiri Aripin sebagai Bupati bersama Ahmad Toha, sebagai Wakil Bupati dengan pengajuan secara independen 


\section{METODE PENELITIAN}

Tipe yang digunakan dalam penelitian ini adalah tipe deskriptif yaitu, suatu bentuk penelitian yang ditunjukan untuk mendeskripsikan fenomena-fenomena yang ada, baik fenomena alamiah maupun fenomena buatan manusia (Faisal, 2008). Pendekatan yang digunakan dalam penelitian ini adalah pendekatan kualitatif, yaitu penelitian ilmiah yang bertujuan untuk memahami suatu fenomena dalam konteks sosial secara alamiah dengan mengedepankan proses interaksi komunikasi yang mendalam antara peneliti dengan fenomena yang diteliti.Dalam konteks penelitian ini, kualitatif dalam penelitian ini adalah memberikan analisis terhadap ke sebelas fungsi partai politik pengusung Dodi Reza dan Beni Hernedi pada pilkada Musi Banyuasin 2017.

Jadi tipe dan pendekatan deskriptif kualitatif adalah untuk memberikan penggambaran secara kualitatif tentang bagaimana peran dan fungsi yang dilakukan partai politik pengusung paslon Dodi Reza dan Beni Henedi pada pilkada Musi Banyuasin 2017.

Jenis penelitian yang digunakan dalam penelitian ini adalah penelitian lapangan (field research). Penelitian lapangan adalah suatu penelitian yang dilakukan secara sistematis dengan mengangkat data yang ada dilapangan. prosedur penelitiannya bersifat menjelaskan, mengambarkan dan menafsirkan hasil penelitian dengan susunan kata atau kalimat sebagai jawaban atas permasalahan yang diteliti berkaitan fungsi partai politik pada pemilihan kepala daerah Musi Banyuasin tahun 2017 berdasarkan analisa terhadap partai politik pengusung pengusung pasangan Dodi Reza dan Beni Hernedi.

\section{HASIL DAN PEMBAHASAN}

\section{A. Fungsi Partai Politik dalam Memenangkan Pilkada}

Pemilihan kepala daerah Kabupaten Musi Banyuasin yang diselenggarakan pada tanggal 15 Februari 2017 diikuti oleh dua pasang kandidat yang mencalonkan dirinya sebagai Bupati dan Wakil Bupati Musi Banyuasin, yaitu nomor urut satu Dodi Reza yang berpasangan dengan Beni Hernedi dan nomor urut dua yaitu Amiri Aripin yang berpasangan dengan Ahmad Toha.

Pada pilkada sebelumnya Dodi Reza juga mencalonkan dirinya sebagai calon Bupati Musi Banyuasin tetapi ia dikalahkan oleh pasangan Pahri Azhari dan Beni Hernedi. Lalu pada pilkada tahun 2017 Dodi Reza kembali mencalonkan dirinya sebagai calon Bupati Musi Banyuasin dan berpasangan dengan Beni Hernedi. Pada pilkada Musi Banyuasin tahun 2017 ini pasangan Dodi Reza dan Beni ditetapkan sebagai pemenang.

Pada pemilihan tersebut pasangan dengan nomor urut 1 diusung oleh 11 (sebelas) partai politik yaitu diantaranya Partai Demokrasi Indonesia Perjuangan (PDI-P), Partai Amanat Nasional (PAN), Partai Gerakan Indonesia Raya (Gerindra), Partai Demokrat, Partai Golongan Karya (Golkar), Partai Nasional Demokrat (Nasdem), Partai Kebangkitan Bangsa (PKB), Partai Keadilan

Sejahtera (PKS), Partai Hati Nurani Rakyat (Hanura), Partai Persatuan Pembangunan (PPP), Partai Bulan Bintang (PBB). Sedangkan pasangan dengan nomor urut dua berasal dari jalur 
Independen.Pada pemilihan tersebut seluruh partai politik yang mengikuti pilkada di Kabupaten Musi Banyuasin berkoalisi dengan Dodi Reza dan Beni Hernedi.

Partai politik mempunyai peranan penting dalam sebuah kompetisi pemilihan kepala daerah, karena fungsi utama dari partai politik itu sendiri untuk mencari kekuasaan, mendapatkan kekuasaan serta mempertahankan kekuasaan. Cara partai politik memperoleh kekuasaan yaitu dengan cara berpartisipasi dalam pemilihan, termasuk dalam pemilihan kepala daerah yang dilakukan di Kabupaten Musi Banyuasin tahun 2017.

Terdapat 11 (sebelas) partai politik yang mengikuti pilkada Kabupaten Musi Banyuasin tahun 2017. Ke 11 (sebelas) partai politik tersebut berpartisipasi dalam pilkada Musi Banyuasin tahun 2017 dengan mengusung paslon nomor urut satu yaitu pasangan Dodi Reza dan Beni Hernedi. Koalisi yang dilakukan oleh ke 11 (sebelas) partai politik tersebut tentu memiliki pertimbangan tersendiri sehingga memutuskan untuk mendukung pencalonan Dodi Reza dan Beni Hernedi.

Dalam politik, kepentingan adalah hal yang abadi. Hal ini terbukti dari koalisi yang dibangun antar partai politik dalam pilkada Musi Banyuasin 2017. Tentunya dalam berkoalisi keuntunganlah yang menjadi pertimbangan. Dari ke 11 (sebelas) partai politik itu juga menganggap bahwa pasangan terkuat dari pada paslon yang lain, sehingga menarik perhatian sebelas partai politik untuk bergabung dalam barisan koalisi paslon Dodi Reza dan Beni Hernedi.

Bagi paslon Dodi Reza dan Beni Henedi, partai politik dianggap penting dalam pemenangan meraka dalam pilkada Musi Banyuasin 2017. Dalam tulisan ini akan diuraikan fungsi dari partai politik dalam sebuah kontestasi pilkada. Kerangka pemikiran yang digunakan adalah dari Miriam Budiardjo yang menyatakan bahwa partai politik berfungsi sebagai sarana komunikasi, sosialisasi politik, rekrutmen politik dan sarana pengelola konflik.

\section{Sarana Komunikasi Politik}

Sarana komunikasi politik bertugas menyalurkan beragam aspirasi masyarakat dan menekankan kesimpangsiuran pendapat di masyarakat. Peran partai politik adalah menjadi wadah penggabungan aspirasi masyarakat yang senada agar dapat dirumuskan secara lebih terstruktur atau teratur. Selanjutnya, tugas partai politik adalah merumuskan aspirasi tersebut menjadi sebuah usulan kebijakan untuk diajukan kepada pemerintah agar menjadi suatu kebijakan publik (Budiarjo, 2008).

Sebagai contoh dari permasalahan ini adalah seperti yang disampaikan oleh Dewi Kurniasih dan Tatik Rohmawati dalam majalah ilmiah UNIKOM yang berjudul Pelaksanaan Fungsi Komunikasi Politik Partai Demokrat (studi pemilihan Walikota Bandung 2013) dalam proses mengimplementasikan fungsi komunikasi politik, partai Demokrat sempat memiliki hambatanhambatan diantaranya adalah sering terjadi miskomunikasi antar kader saat menyampaikan program-program partai politik atau menerima aspirasi dari masyarakat (Kurniasih, 2013).

Hal ini disebabkan oleh masih rendahnya kualitas sumber daya manusia dari partai Demokrat Kota Bandung karena anggota partai Demokrat yang memiliki kualitias pendidikan yang 
masih rendah sehingga untuk mengatasi hal itu Dewan Pengurus Cabang Demokrat (DPC) kota Bandung melakukan pendidikan politik yang diadakan dengan jadwal tersendiri secara khusus dan terpisah dari agenda-agenda lainnya. Hal ini berdampak positif terhadap pengetahuan anggota partai terhadap fungsi-fungsi partai politik terutama fungsi partai politik sebagai sarana komunikasi politik.

\section{Sarana Sosialisasi Politik}

Menurut Miriam Budiardjo dalam ilmu politik sosialisasi politik diartikan sebagai suatu proses yang denganya seseorang memperoleh sikap dan orientasi terhadap fenomena politik. Yang umumnya berlaku dalam masyarakat dimana ia berada. Sosialisasi politik adalah bagian dari proses yang menentukan sikap politik seseorang misalnya mengenai nasionalisme, kelas sosial, suku bangsa, ideologi, hak dan kewajiban.

Sosialisasi politik juga merupakan proses yang digunakan oleh masyarakat, untuk menyampaikan budaya politik yaitu norma-norma dan nilai-nilai dari suatu generasi ke generasi berikutnya dengan demikian sosialisasi politik merupakan faktor penting dalam terbentuknya budaya politik suatu bangsa.15 Sisi lain dari fungsi sosialisasi partai politik adalah upaya untuk menciptakan citra bahwa ia memperjuangkan kepentingan umum. Ini penting jika dikaitan dengan tujuan partai untuk menguasai pemerintahan melalui kemenangan dalam pemilihan umum. Karena itu partai politik harus memperoleh dukungan seluas mungkin, dan partai berkepentingan agar para pendukungnya mempunyai solidaritas yang kuat dengan partainya.

Hal paling utama apabila partai politik dapat menjalankan fungsi sosialisasi politik yakni mendidik anggota - angotanya menjadi manusia yang sadar akan tanggung jawabnya sebagai warga negara dan menepatkan kepentingan nasional diatas kepentingan pribadi. Hal ini seperti yang dilakukan oleh Partai Amanat Nasional pada saat memenangkan Pilkada tahun 2013 di Kabupaten OKI dengan mengusung pasangan Iskandar, SE dan M.Rifai, SE. Langkah pertama yang dilakukan oleh Partai Amanat Naional adalah membentuk tim koalisi dengan partai lain sehingga terbentuklah koalisi empat partai yaitu PAN, Hanura, Gerindra dan PKB (Aprizal, 2017).

Adanya koalisi partai ini kemudian dimanfaatkan untuk mensosialisasikan programprogram unggulan paslon dengan cara menjalin komunikasi dan silahturahmi dari desa kedesa selain itu, disosialisasikan juga program-program yang berkaitan dengan pembangunan kesejahteraan masyarakat OKI. Sehingga dengan sosialisasi politik yang baik yang dilakukan oleh koalisi partai tersebut pasangan Iskandar, SE dan M.Rifai, SE berhasil memenangkan pilkada OKI 2013 dengan perolehan suara 124.050 yang mengungguli lima paslon lainnya.

Melalui sosisalisasi politik yang baik dengan partai lain untuk membentuk koalisi serta sosialisasi yang berjalan baik dengan cara menemui masyarakat dari desa kedesa dan menyampaikan program pembangunan kesejahteraan masyarakat adalah poin-poin penting sosialisasi politik PAN untuk memenangkan Paslon yang diusungnya dan hal itu terbukti efektif dengan pasangan Iskandar, SE dan M. Rifai, SE. 


\section{Sarana Rekrutmen politik}

Fungsi partai politik sebagai sarana rekrutmen politik berkaitan erat dengan masalah kepemimpinan baik kepemimpinan internal partai maupun kepemimpinan nasional yang lebih luas. Untuk kepentingan internalnya, setiap partainya butuh kader-kader yang berkualitas, karena hanya dengan kader yang demikian ia akan menjadi partai yang mempunyai kesempatan paling besar untuk mengembangkan diri dengan mempunyai kader-kader yang baik, cerdas, partai tidak akan sulit menentukan pemimpinnya sendiri dan mempunyai peluang untuk mengajukan calon untuk masuk ke bursa kepemimpinan nasional (Meilandi, 2018).

Selain itu, partai politik juga berkepentingan memperluas atau memperbanyak keanggotaan maka partai berusaha menarik sebanyak-banyaknya orang untuk menjadi anggotanya. Rekrutmen politik menjamin keberlangsungan dan kelestarian partai, sekaligus merupakan salah satu cara untuk melatih calon-calon pemimpin. Proses rekrutmen politik terdiri dari beberapa cara yaitu: 1 . Seleksi pemilihan melalui ujian, 2. Latihan (training) hal tersebut menjadi indikator utama didalam perekrutan politik, 3.Penyortiran (memilih yang terbaik), 4.Rotasi memiliki tujuan mencegah terjadinya dominasi jabatan dari kelompok-kelompok yang berkuasa maka perlu adanya pergantian secara periode dalam jabatan-jabatan politik, 5.Petronag artinya suatu jabatan dapat dibeli dengan mudah melalui relasi-relasi terdekat, 6.Koopsi (pemilihan anggota-anggota baru) artinya memasukkan orang-orang atau anggota baru untuk menciptakan pemikiran yang baru sehingga membawa suatu partai pada visi dan misi yang ditujunya.

Adapun contoh dari rekrutmen politik yang baik yang dilakukan oleh partai politik adalah seperti contoh yang dilakukan oleh Partai Amanat Nasional pada pilkada di Kabupaten OKI 2013. Dimana partai PAN dengan keyakinannya mencalonkan kadernya sendiri Iskandar, SE hal ini diputukan oleh PAN karena Iskandar, SE merupakan kader terbaik mereka yang siap untuk memimpin Kabupaten OKI. Selain itu, PAN juga mengklaim bahwa Iskandar, SE merupakan kader yang disenangi masyarakat dan memiliki karismatik sebagai calon pemimpin.

Keputusan PAN ini mencalonkan kadernya sendiri yang dianggap memumpuni mengemban tanggung jawab sebagai pemimpin OKI ternyata mendapat respon yang baik dari masyarakat dan terbukti dengan kemenangannya pada Pilkada OKI tahun 2013 dan mengalahkan lima paslon lainnya. Hal ini menunjukkan bahwa ketika sebuah partai memiliki kader-kader yang baik tentu partai tersebut akan memiliki kepercayaan diri yang tinggi untuk mencalonkan kadernya sendiri sebagai pemimpin masyarakat.

Sebaliknya jika sebuah partai tidak memiliki kader yang memadai maka tidak akan ada kepercayaan diri dari partai tersebut untuk mencalonkan kadernya sehingga partai tersebut lebih memilih berkoalisi dengan partai lain dan mendukung paslon yang diusung oleh partai tersebut.

\section{Sarana Pengatur Konflik}

Potensi konflik selalu ada di setiap masyarakat, apalagi dimasyarakat terdiri dari berbagai macam etnis (suku bangsa, sosial ekonomi ataupun agama). Setiap perbedaan tersebut menyimpan potensi 
konflik. Apabila keanekaragaman itu terjadi di negara yang menganut paham demokrasi, persaingan dan perbedaan pendapat dianggap hal yang wajar.

Disini peran partai politik diperlukan untuk membantu mengantasinya, atau sekurangkurangnya dapat diatur sedemikian rupa sehingga akibat negatifnya dapat ditekan seminimal mungkin. Elit partai dapat menumbuhkan pengertian diantara mereka dan bersamaan dengan itu juga meyakinkan pendukungnya.

Secara ringkas dapat dikatakan bahwa partai politik dapat menjadi penghubung psikologis dan organisasional antara warga negara dengan pemerintahnya. Selain itu partai juga melakukan konsolidasi terhadap tuntutan-tuntutan yang beragam yang berkembang diberbagai kelompok masyarakat. Pelaksanaan fungsi ini dapat dijadikan instrumen untuk mengukur keberhasilan atau kegagalan partai politik di negara demokrasi. Karena dipihak lain dapat dilihat bahwa seringkali partai malah mempertajam pertentangan yang ada jika hal ini terjadi maka dapat membahayakan stabilitas politik.

Contoh dari permasalahan ini adalah seperti yang ditulis oleh Alex Sander dalam skripsinya yang berjudul Marketing Politik Partai Demokrasi Indonesia Perjuangan dalam Pemilihan Kepala Daerah Kabupaten OKI tahun 2018, yang mengatakan bahwa partai PDI-P pada pilkada tahun 2018 mencalonkan pasangan Abdiyanto dan Made Indrawan, hal ini dianggap efektif untuk meredam konflik antara masyarakat asli dan masyarakat pendatang. Seperti yang diketahui bahwa Abdiyanto merupakan putra daerah Kabupaten OKI sementara Made Indrawan merupakan suku pendatang yaitu suku Bali (Sander, 2019).

Dengan mengajukan paslon ini diharapkan agar tidak terjadinya konflik antara masyarakat mayoritas dan minoritas sehingga masyarakat menilai partai PDI-P merupakaan partai yang perduli terhadap kaum mayoritas maupun minoritas. Sehingga masyarakat akan simpati dan memilih pasangan calon yang diusung oleh partai PDI-P tersebut. Hal ini terbukti dengan perolehan suara Abdiyanto dan Made Indrawan yang mencapai 32,92\% padahal hanya diusung oleh satu partai saja semantara pemenang pilkada pasangan Iskandar dan M Dja'far Sodik yang merupakan petahana dan diusung oleh lima partai hanya mendapatkan perolehan suara 46,80\%.

Adapun contoh yang lain misalnya terjadi sengketa lahan antara pemerintah dengan masyarakat ketika adanya pembangunan proyek pemerintahan, partai politik hadir untuk menjadi penengah dari permasalahan tersebut, agar ditemukan suatu solusi yang tepat untuk menyelesaikan sengketa tersebut.

\section{B. Fungsi partai politik pengusung paslon Dodi Reza dan Beni Hernedi dinilai dari hasil perolehan suara pada Pilkada Musi Banyuasin 2017}

Pada bagian ini peneliti akan memaparkan mengenai apa saja yang peneliti temukan di lapangan, siapa saja yang menjadi objek peneltian serta peneliti akan menganalisis semua permasalahan yang ada mengunakan 4 (empat) fungsi partai politik menurut Miriam Budiardjo. Dalam proses Pilkada fungsi partai sangat diperlukan untuk memenangkan kontestasi Pilkada. Dengan adanya fungsi 
partai yang baik dan berjalan sesuai dengan fungsi partai politik yang sesungguhnya maka apa yang menjadi tujuan bersama dari partai politik akan mudah untuk direalisasikan.

Pada tahap ini peneliti akan menganalisis bagaimana ke 6 (enam) partai politik pengusung Dodi Reza dan Beni Hernedi yaitu Golkar, PDIP, Demokrat, Nasdem, PKB dan Hanura dalam menjalankan fungsi partai berdasarkan 4 (empat) fungsi partai menurut Miriam Budiardjo. Pembahasan pertama peneliti adalah partai Golkar, karena Dodi Reza yang maju sebagai Bupati Musi Banyuasin merupakan kader dari partai Golkar. Sehingga peneliti tertarik untuk menganalisis partai Golkar terlebih dahulu untuk mengetahui sejauh mana partai Golkar menjalankan fungsi partai terutama dalam memenangkan kadernya.

Partai Golkar melakukan langkah-langkah untuk memenangkan paslon Dodi Reza dan Beni Hernedi. Seperti halnya sosialisasi politik, partai Golkar mengikut sertakan Setya Novanto yang menjabat sebagai ketua DPR RI sekaligus ketua umum DPP Partai Golkar pada saat itu untuk ikut serta secara langsung dalam agenda sosialisasi politik, yang juga dimeriahkan oleh artis ibukota. Setya Novanto bersama dengan DPD partai Golkar melakukan sosialisasi untuk meyakinkan masyarakat agar memilih pasangan Dodi Reza dan Beni Hernedi pada Pilkada Musi Banyuasin 2017.

Fungsi selanjutnya yang akan dianalisis oleh peneliti yaitu fungsi rekrutmen politik yang dilakukan oleh partai Golkar. Jika melihat dari Pilkada Musi Banyuasin 2017 rekrutmen politik yang dilakukan oleh partai Golkar sudah cukup baik, hal ini karena paslon yang diusung merupakan kader dari partai Golkar itu sendiri. Selain itu, partai Golkar juga dalam hal rekrutmen ini cukup aktif dalam merekrut partai-partai yang lain untuk ikut serta mengusung Dodi Reza sebagai calon Bupai Musi Banyuasin 2017.

Adapun dalam hal komunikasi politik, partai Golkar sebenarnya juga sudah cukup baik dalam mengimplementasikan fungsi partai sebagai komunikasi politik pada Pilkada Musi Banyuasin 2017. Namun kembali lagi bahwa partai Golkar hanya melakukan fungsi Komunikasi Politiknya pada saat pilkada saja dan tidak ada program-program khusus yang berkenaan dengan komunikasi politik yang diakukan diluar masa Pilkada.

Adapun dalam hal sarana pengendali konflik, partai Golkar tidak memiliki beban yang cukup berat dalam hal pengendalian konflik ini karena Kabupaten Musi Banyuasin itu sendiri merupakan Kabupaten yang jauh dari pemberitaan mengenai adanya konflik baik suku, ras, agama serta konflik antara pemerintah dengan masyarakat. Namun, partai Golkar sebagai partai pengusung utama paslon Dodi Reza dan Beni Hernedi memiliki tugas yang berat untuk mengetahui apa yang sebenarnya menjadi alasan masyarakat tidak ikut serta dalam Pilkada Musi Banyuasin 2017.

Dari ke 4 (empat) fungsi partai politik yang dijalankan oleh partai Golkar tersebut dapat dilihat bahwa dalam hal rekrutmen politik partai golkar sudah cukup baik karena berani mencalonkan kadernya sendiri serta bisa mengajak partai-partai yang lain untuk mengusung kadernya, namun dalam hal sosialisasi politik ada titik kelemahan daripartai Golkar, karena partai Golkar hanya melakukan sosialisasi politik secara aktif pada saat Pilkada saja sehingga, alasan 
upaya membuat program melalui kampanye dialogis hanya sekedar formalitas saja dan tidak sungguh-sungguh mengambil aspirasi masyarakat sebagai suatu program.

Adapun dalam hal rekrutmen politik, partai PDIP sebenarnya sudah cukup baik dengan mengajukan kadernya yaitu Beni Hernedi untuk mencalonkan diri sebagai wakil Bupati Musi Banyuasin mendampingi Dodi Reza. Namun,sebenarnya partai PDIP memiliki peluang yang sangat besar untuk mencalonkan Beni Hernedi sebagai calon Bupati Musi Banyuasin karena sebelumnya Beni merupakan Wakil Bupati Musi Banyuasin Periode pertama sejak 15 januari 2012 hingga 24 Desember 2015 dan ia juga pernah menjabat sebagai pelaksana tugas Bupati Musi Banyuasin 24 Desember 201 hingga 15 Januari 2017.

Dengan status Beni Hernedi sebagai petahan, dan Dodi Reza sebagai lawan politik yang sempat dikalahkannya pada Pilkada Musi Banyuasin 2012 seharusnya partai PDIP lebih percaya diri mencalonkan Beni Hernedi sebagai calon Bupati bukan sebagai Wakil Bupati dari Dodi Reza. Jika PDIP memberanikan diri mencalonkan Beni Hernedi sebagai calon Bupati Musi Banyuasin 2017 tentu akan memunculkan persaingan yang sehat dan akan menimbulkan keinginan dari masyarakat untuk memilih.

Namun yang terjadi adalah partai PDIP malah menjadikan Beni Hernedi sebagai calon Wakil Bupati dari Dodi Reza. Sehingga paslon Dodi Reza dan Beni Hernedi diusung oleh 2 partai yaitu Golkar dan PDIP ditambah 9 (sembilan) partai politik yang lain, sementara lawan politiknya Amiri Aripin dan Ahmad Toha merupakan pasangan yang independen. Hal ini menyebabkan persaingan politik yang tidak menarik yang mengakibatkan masyarakat bosan dan tidak berkeinginan untuk ikut serta dalam Pilkada Musi Banyuasin 2017. Sehingga hal tersebut terbukti dengan jumlah golput yang mencapai $42 \%$.

Adapun dalam hal komunikasi dan pengendalian konflik partai PDIP memiliki kesamaan dengan partai Golkar karena PDIP hanya aktif melakukan komunikasi politik pada saat kampanye saja. Sosialisasi juga dilakukan oleh partai Nasdem yang bebar-benar melakukan sosialisasi politik secara maksimal, hal ini terbuki dengan keikutsertaan Syahrial Oesman sebagai Ketua Dewan Pengurus Wilayah partai Nasdem Sumatera Selatan, dalam agenda sosialisasi politik yang dilakukan oleh pengurus partai Nasdem Kabupaten Musi Banyuasin.

Dalam hal rekrutmen politik partai Nasdem mempunyai kelemahan karena rekrutmen politik yang dilakukan partai Nasdem kurang berjalan dengan baik di Kabupaten Musi Banyuasin. Bahkan partai Nasdem hanya memiliki 2 kursi DPRD Kabupaten Musi Banyuasin yang membuat partai Nasdem kesulitan untuk mencalonkan kadernya sendiri serta harus berkoalisi dengan partai lain.

Adapun dalam hal pengendalian konflik, partai Nasdem juga memiliki tanggung jawab yang sama seperti partai Golkar dan PDIP untuk mengetahui permasalahan apa yang terjadi antara pemerintah dan masyarakat agar tidak menimbulkan suatu konflik yang lebih besar lagi, upaya tersebut sudah dilakukan oleh partai Nasdem dengan adanya komunikasi politik yang dilakukan oleh partai Nasdem di desa-desa. 
Dari ke 4 (empat) fungsi partai politik yang dilakukan oleh partai Nasdem diatas dapat dipahami bahwa kelemahan dari partai Nasdem adalah pada tahap rekrutmen politik dimana partai Nasdem tidak secara aktif melakukan pengkaderan atau melakukan pendidikan kader agar memunculkan kader-kader yang berkualitas, sehingga membuat partai Nasdem kesulitan ntuk bersaing dengan partai - partai lain dan memutuskan untuk bergabung dengan partai-partai yang lain untuk mengusung pasangan Dodi Reza dan Beni Hernedi.

Dalam hal komunikasi politik juga partai Nasdem memiliki kelemahan karena kader-kader yang memiliki kualitas yang rendah menyebabkan penyampaian komunikasi politik yang kurang baik sehingga sulit dipahami oleh masyarakat, serta sering terjadinya miskomunikasi pusat dan daerah. Permasalahan ini sebenarnya sama dengan yang dialami oleh DPC partai Demokrat Kota Bandung namun, DPC Partai Demokrat Kota Bandung mengatasi permasalahanya dengan melakukan pendidikan politik secara khusus kepada kader-kadernya dan berhasil membuat kualitas kadernya lebih baik.

Partai Demokrat yang juga merupakan partai pengusung pasangan Dodi Reza dan Beni Hernedi dalam menjalankan fungsi partai politik sebagai sosialisasi politik juga memiliki cara-cara tersendiri yaitu dengan memberi informasi serta instruksi kepada seluruh petugas-petugas ranting partai Demokrat yang ada di desa untuk mensosialisasikan program Dodi Reza dan Beni Hernedi yang maju dalam Pilkada 2017. Sekretaris Jendral DPC Partai Demokrat Kabupaten Musi Banyuasin juga mengatakan bahwa mereka merancang pemetaan disetiap desa maupun disetiap Kecamatan untuk pemenangan calon yang mereka usung.

Dari apa yang sudah dilakukan partai Demokrat berdasarkan informasi yang didapatkan peneliti dari Sekretaris Jenidral DPC Partai Demokrat dapat diketahui bahwa partai Demokrat sudah menjalankan fungsinya sebagai sarana sosialisasi politik pada saat Pilkada Musi Banyuasin 2017 dengan cara pemetaan pemenangan disetiap desa dan Kecamatan serta memberikan instruksi kepada seluruh petugas-petugas ranting untuk mensosialisasikan program Dodi Reza dan Beni Hernedi.

Adapun dalam hal fungsi partai politik sebagai sarana rekrutmen politik, partai Demokrat sebenarnya sudah menjalankan fungsinya dengan baik hal ini, terlihat dari keterwakilan kader mereka dalam lembaga Legislatif Kabupaten Musi Banyuasin karena partai Demokrat memiliki 3 (tiga) perwakilan di kursi DPRD Kabupaten Musibanyuasin. Hanya saja partai Demokrat membutuhkan kaderisasi yang lebih maksimal lagi agar memunculkan kader-kader yang lain yang juga siap bersaing dalam kontestasi Pilkada maupun Pileg.

Dalam hal fungsi partai politik sebagai sarana pengatur konflik partai Demokrat dengan 3 (tiga) perwakilannya yang ada di lembaga legislatif tentu memiliki tanggung jawab untuk menyelesaikan jika terjadi suatu konflik baik antar masyarakat maupun pemerintah dengan masyarakat.

Dari penjelasan diatas dapat disimpulkan bahwa partai Demokrat cukup lemah dalam hal rekrutmen politik, karena DPC Partai Demokrat Kabupaten Musi Banyuasin belum melakukan kaderisasi secara maksimal, serta memberikan tingkatan-tingkatan pendidikan terhadap kader 
sehingga pengurus ranting dari partai belum bisa secara maksimal mensosialisaikan apa-apa yang menjadi program yang dijanjikan oleh paslon yang mereka usung. Hal ini dikarenakan kurangnya tingkat pemahaman dari pengurus ranting partai terhadap informasi-informasi yang diperoleh oleh pengurus cabang maupun pusat.

Partai politik pengusung pasangan Dodi Reza dan Beni Hernedi yang lainya yaitu Partai PKB (Partai Kebangkitan Bangsa) sebenarnya sudah melakukan proses kaderisasi partai dan rekrutmen yang cukup baik. Hal ini terlihat dari adanya keterwakilan partai PKB dalam lembaga legislatif yang berjumlah 5 (lima) kursi, itu artinya bahwa PKB hanya membutuhkan 4 (empat) kursi saja untuk bisa mencalonkan kadernya sendiri pada Pilkada Musi Banyuasin 2017.

Dengan rekrutmen yang baik ini dan memiliki kader-kader yang siap bersaing seharusnya partai PKB memiliki kepercayaan diri untuk berkoalisi dengan partai yang lain untuk mencalonkan kadernya. Namun ternyata dengan pertimbangan hasil survei serta partai-partai yang lain yang memutuskan mengusung paslon Dodi Reza dan Beni Hernedi membuat PKB juga ikut serta dalam koalisi tersebut.

Adapun dalam hal sosialisasi politik dengan kader-kader yang berkualitas partai PKB mengaku bahwa mereka mensosialisakan paslon yang mereka usung tersebut kepada pengurus, kader dan dengan konstituen PKB se-Kabupaten Musi Banyuasin meskipun dalam kenyataannya peneliti tidak menemukan dokumen-dokumen atau berita yang berkenaan dengan kampanye politik DPC Partai PKB pada Pilkada Musi Banyuasin 2017, hal ini berbeda dengan partai-partai lain yang peneliti temukan dokumennya serta berita-beritanya dimedia masa.

Dari permasalahan tersebut dapat dipahami bahwa partai PKB meskipun sudah memiliki kader yang cukup baik namun belum maksimal dalam hal sosialisasi politik. Dalam hal komunikasi politik DPC Partai PKB juga tidak melakukan komunikasi politik secara maksimal. Hal ini disebabkan oleh tingkat kepercayaan mereka yang cukup tinggi terhadap paslon yang mereka usung karena dalam dalam beberapa kali survei paslon yang mereka usung selalu menang.

Sementara itu, partai Hanura yang juga sebagai partai pengusung pasangan Dodi Reza dan Beni Hernedi dalam menjalankan fungsinya sebagai sarana sosialisasi politik juga mensosialisasikan paslon Dodi Reza dan Beni Hernedi ditingkat internal maupun eksternal partai guna untuk menarik simpatisan masyarakat agar memilih Bupati dan Wakil Bupati yang diusung oleh partai, selain itu partai Hanura juga mengharapkan kepada masyarakat untuk memilih (tidak golput).

Apa yang dilakukan oleh partai Hanura tersebut sudah cukup baik dalam hal sosialisasi politik karena partai Hanura ketika menemui masyarakat bukan hanya mensosialisasikan paslon yang mereka usung saja melainkan juga mensosialisaikan bagaimana pentingnya datang ke TPS untuk memilih atau memberikan kontribusinya untuk daerah selama 5 (lima) tahun kedepan.

Sementara dalam hal rekrutmen politik partai Hanura juga cukup baik karena partai Hanura memiliki perwakilan sebanyak 5 (lima) kursi di DPRD Kabupaten Musi Banyuasin, hanya saja partai Hanura kurang baik dalam hal komunikasi politik dengan partai yang lain karena tidak mampu membentuk koalisi yang lain diluar paslon Dodi Reza dan Beni Hernedi. Sementara dalam 
hal pengendali konflik partai Hanura juga mengaku siap untuk menyelesaikan berbagai konflik dimasyarakat karena hal itu merupakan salah satu tugas dari partai politik yang harus dilaksanakan.

Dari keenam partai pengusung paslon Dodi Reza dan Beni Hernedi diatas dapat dipahami bahwa penyebab rendahnya partisipasi masyarakat pada Pilkada Kabupaten Musi Banyuasin 2017 disebabkan oleh beberapa hal yaitu: pertama, sosialisasi politik yang dilakukan oleh partai pengusung paslon Dodi Reza dan Beni Hernedi hanya dilaksanakan secara maksimal pada saat Pilkada atau Pileg saja sementara diluar dari agenda tersebut hampir-hampir setiap partai pengusung tersebut tidak memiliki agenda yang mengikutsertakan masyarakat.

Sehingga sosialisasi politik yang diakui oleh partai pengusung sebagai sarana untuk membuat visi dan misi adalah sesuatu yang formalitas saja karena sebenarnya partai politik dan koalisinya sudah memiliki visi dan misi tersendiri. Sehingga menurut mereka yang mengikutsertakan masyarakat dalam pembuatan visi misi merupakan sesuatu yang tidak mereka lakukan, karena tanya jawab pada saat sosialisasi politik berlangsung merupakan sesuatu yang formalitas saja.

Kedua,partai-partai pengsung pasangan Dodi Reza dan Beni Hernedi memiliki pola yang sama dalam hal mensosialisasikan program merka kepada mayarakat bahkan terkadang mereka melakukan agenda kunjungan kepada masyarakat dengan bersama-sama padahal jika setiap partai memiliki pola sosialisasi yang berbeda-beda dan ditugaskan diposisi yang berbeda-beda tentu akan menghasilkan perolehan suara yang lebih baik lagi untuk paslon yang mereka usung. Pola yang sama yang dilakukan oleh beberapa partai pengusung paslon Dodi Reza dan Beni Hernedi hanya akan menimbulkan kejenuhan dari masyarakat sehingga meskipun sosialisasi itu dilakukan secara berulang-ulang tidak akan berpengaruh terhadap masyarakat.

Ketiga, kepercayaan diri dari partai pengusung pasangan Dodi Reza dan Beni Hernedi yang terlalu tinggi menyebabkan beberapa partai politik tersebut tidak melakukan fungsi partai politiknya secara benar sehingga dengan jumlah sumberdaya manusia yang besar karena diusung oleh sebelas partai tidak bisa menghasilkan suara yang maksimal disebabkan karena kepercayaan diri partai politik tesebut.

Keempat, tidak adanya keberanian dari partai politik untuk membuat koalisi diluar pasangan Dodi Reza dan Beni Hernedi menyebabkan persaingan pada Pilkada Musi Banyuasin 2017 tidak seimbang, karena disatu sisi paslon diusung oleh sebelas partai sementara paslon yang lainnya maju secara independen. Adanya ketidak seimbangan kompetisi tersebut menyebabkan masyarakat apatis terhadap pemilihan kepala daerah 2017 karena sudah pasti diketahui siapa yang akan keluar menjadi pemenangnya. Keempat poin tersebut menurut peneliti merupakan penyebab dari rendahnya tingkat partisipasi masyarakat pada Pilkada Musi Banyuasin 2017.

\section{KESIMPULAN}

Berdasarkan penelitian yang telah dilakukan oleh peneliti tentang Analisa Fungsi Partai Politik Pengusung Pasangan Dodi Reza dan Beni Hernedi pada Pilkada 2017 (Studi Terhadap Partai 
Politik Pengusung Pasangan Dodi Reza dan Beni Hernedi) dapat disimpulkan bahwa dari ke 4 fungsi partai politik menurut Miriam Budiardjo tersebut sebenarnya sudah dilakukan hanya saja masih terdapat kekurangan-kekurangan yang harus diperbaiki oleh beberapa partai tersebut seperti dalam hal rekrutmen politik seharusnya partai memiliki sistem rekrutmen yang baik bukan hanya seorang tokoh atau pengusaha dan kemudian dijadikan sebagai anggota partai tetapi lebih kepada proses pengkaderan agar terciptanya kader-kader yang berkualitas dan militan serta siap untuk berkompetisi ditingkat lokal maupun nasional.

Fungsi partai politik sebagai sarana komunikasi politik dimana diperlukan ide-ide cemerlang dari kader agar terciptanya suatu proses kampanye yang menarik dan tidak monoton sehingga menimbulkan efek yang signifikan terhadap dukungan kepada paslon yang diusung. Selain itu, adanya kompetisi yang tidak seimbang karena satu paslon diusung oleh 11 (sebelas) partai sedangkan paslon lyang lainnya maju dari jalur independen.

Berdasarkan dari penelitian diatas penulis menyarankan beberapa hal mengenai fungsi partai politik yang dilakukan oleh partai politik pengusung Dodi Reza dan Beni Hernedi. Pertama adalah partai politik harus memiliki ide-ide yang cemerlang dan kreatif dalam hal berkampanye dan menyampaikan visi dan misi calon sehingga bisa menarik simpati dari masyarakat. Yang kedua harus ada perbaikan dalam proses rekrutmen partai politik agar terciptanya persaingan politik yang sehat dan seimbang sehingga menimbulkan kompetisi yang menarik dan membuat masyarakat tertarik untuk mengikutinya. 


\section{DAFTAR PUSTAKA}

Azra, Azyumardi. (2000). Demokrasi, Hak Asasi Manusia, Masyarakat Madani. Jakarta : ICCE UIN

Budiardjo, Miriam. (2008). Dasar-Dasar Ilmu Politik. Jakarta: PT Gramedia Pusaka Utama

Budiardjo, Miriam. (2012). Dasar-Dasar Ilmu Politik, (Jakarta ; Gramedia Pustaka Utama

Dalton J, Russel, Martin P. Wattenberg. (2000). Parties Without Partisans Political Change in Advanced Industrial Democracies, New York : Oxford University Press

Firmanzah. (2011). Mengelola Partai Politik. Jakarta : Yayasan Pustaka Obor Indonesia

Hadi, Sutrisno. (1987), Metodologi Research II, Yogyakarta: AndiOffiset

Herdiansyah, Haris. (2010). Metodologi Penelitian Kuantitatif. Jakarta : Salemba Humanika.

Labolo, Muhadam. (2015). Partai Politik Dan Sistem Pemilihan Umum Di Indonesia. Jakarta PT RajaGrafindo Persada

Lexy, Meolong. (2006). Metode Penelitian Kualitatif. Bandung: PT Remaja Rosdakarya

Meilandi, R. (2018). Strategi Partai Koalisi dalam Pemenangan AW Nofiadi Mawardi-Ilyas Panji Alam pada Pemilihan Kepala Daerah Kabupaten Ogan Ilir Tahun 2015. Jurnal Studi Sosial dan Politik, 2(1), 31-43.

Mile, Mathew B, Huberman Michael. (1992). Analisis Data Kualitatif BukuSumber Tentang Metode-Metode Baru, Jakarta: UI Pres

Neumann, Sigmund. (1963). Modern Political Parties dalam Comparative Politics : A Reader, edited oleh Harry Eckstein dan David E. Apter. London: The Free Press of Glencoe

Plano, Jack dkk. (1985). Kamus Analisis Politik, (terj.). Jakarta : Rajawali

Rasyid, Tarech. (2017). Pengantar Ilmu Politik. Yogyakarta : Idea Press

Sanapiah, Faisal. (2008). Format-format Penelitian Sosial, Jakarta: Rajawali Pers

Schlesinger, Joseph. (2014). Partai Politik, Terj. Ahmad Asnawi (Bandung : Nusa Media

Syahrial, Syarbaini. (2011). Pengetahuan Dasar Ilmu Politik (Bogor : Penerbit Ghalia Indonesia

Taupan, M. (1989). .Demokrasi Pancasila.Jakarta : Sinar Grafika 